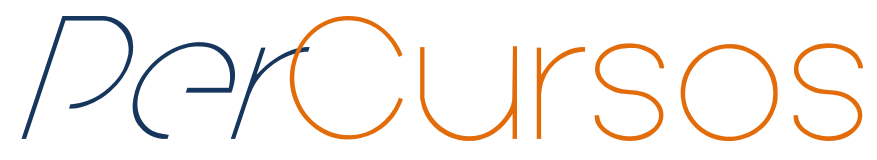

\title{
Com choros, súplicas e comoções: o luto nos perfis pessoais de falecidos na rede social do Orkut no Brasil (2004-2011)
}

\section{Resumo}

Este artigo, intitulado "Com choros, súplicas e comoções: o luto nos perfis pessoais de falecidos na rede social do Orkut no Brasil (20042011)", procura analisar como em tempos de morte silenciada, o Orkut, uma rede social de comunicação e relacionamento, tornou-se um ambiente para expressar e compartilhar a dor e o sofrimento de enlutados, através de mensagens textuais e imagens. Nas páginas da rede social do Orkut, após sua criação no ano de 2004, tanto nas comunidades como em perfis pessoais, observa-se que os enlutados expressam virtualmente sua dor e sofrimento através de imagens e mensagens, sendo estas visíveis e compartilhadas aos usuários de sua rede, podendo ser amigos, familiares e até mesmo desconhecidos. Assim, uma das principais propostas deste trabalho é a de compreender as novas formas de sociabilidade e as variadas relações e interações vivenciadas pelos internautas no espaço virtual, além de esboçar a utilização das páginas da internet como um documento para o campo da história. O trabalho também procura compreender por meio das páginas do Orkut, analisadas como fontes de pesquisa, as relações e distinções entre essas novas formas virtuais de expressar a dor causada pela morte do ente querido e a individualização da dor da perda, característico do luto contemporâneo.

Palavras-chave: Internet. Orkut. Luto. Rituais de morte. Morte contemporânea.

\author{
Julia Massucheti Tomasi \\ Doutoranda em História pela \\ Universidade Federal de Santa \\ Catarina - UFSC \\ juliamtomasi@hotmail.com
}

\section{Para citar este artigo:}

TOMASI, Julia Massucheti. Com choros, súplicas e comoções: o luto nos perfis pessoais de falecidos na rede social do Orkut no Brasil (2004-2011). Revista PerCursos. Florianópolis, v. 14, n.27, jul./dez. 2013. p. $271-303$.

DOI: $10.5965 / 1984724614272013271$

http: //dx.doi.org/10.5965/1984724614272013271 


\title{
With cries, pleas and \\ commotions: mourning the personal profiles of deceased people at Orkut social network in Brazil (2004-2011)
}

\begin{abstract}
This work, entitled "With cries, pleas and commotions: mourning the personal profiles of deceased people at Orkut social network in Brazil (2004-2011) " analyzes how at times of silenced death, Orkut, a social, communication and relationship network, has become an environment to express and share the pain and suffering of the bereaved through text messages and pictures. In the pages of Orkut social network, after its creation in 2004, both in communities and in personal profiles, it is observed that virtual mourners express their pain and suffering through images and messages, which are shared and visible to users in their network, that can be friends, family and even strangers. Thus, one of the main aims of this work is to understand the new forms of sociability and the various relationships and interactions experienced by Internet users in the virtual space, in addition to outlining the use of websites as a document for the field of history. The study also seeks to understand through the pages of Orkut, analyzed as research sources, relations and distinctions between these new virtual forms of expressing the pain caused by the death of their loved ones and the individualization of the pain of loss, characteristic of contemporary mourning.
\end{abstract}

Keywords: Internet. Orkut. Mourning. Death rituals. Death contemporary. 


\section{Introdução}

Criar comunidades na rede social do Orkut para homenagear um ente falecido, parabenizar o morto por seu aniversário e demonstrar dor e saudade nas páginas de recados de perfis pessoais de falecidos são algumas das manifestações post-mortem encontradas na internet. Para muitos usuários brasileiros do Orkut essas práticas ainda são desconhecidas, apesar de estarem presentes desde a criação da rede de sociabilidade, no ano de $2004^{1}$, o luto no espaço virtual é encontrado em diversos perfis de usuários que já morreram ou comunidades criadas para homenageá-los.

A rede social do Orkut tornou-se um espaço virtual que possibilita ao enlutado manter presente a memória do ente morto tanto nas comunidades como também nos perfis pessoais dos falecidos. Observa-se que os enlutados expressam virtualmente seu pesar através de imagens e mensagens, como através de lembrancinhas de morte, fotografias da sepultura do falecido, ou por meio de recados deixados ao ente morto. Assim, o artigo procura compreender como em tempos de morte interdita e introspectiva, o Orkut, uma rede social de comunicação e relacionamento, tornou-se um ambiente para praticar rituais post-mortem através dos perfis pessoais dos enlutados e falecidos.

\section{O luto na contemporaneidade}

Antes de explorar algumas reflexões acerca dos rituais post-mortem no Orkut, deve-se compreender o luto. Palavra que carrega consigo sentido de dor e tristeza, o luto tem variados significados, mas quando mencionado, é logo associado aos sentimentos de perda pela morte de alguém. No decorrer da história, o luto foi vivenciado de diferentes formas. Na Idade Média, por exemplo, o enlutado tinha que expressar sua dor da perda

\footnotetext{
${ }^{1} \mathrm{O}$ Orkut foi criado em 24 de janeiro de 2004 por um ex-aluno da Universidade de Stantford, o engenheiro turco Orkut Buyukokkten, e posteriormente lançado pelo Google (BARBOSA, 2009b, p. 1). A rede social abrange perfis pessoais e comunidades. No primeiro, acessado através de email e senha, é possível criar perfil com dados pessoais, preferências do usuário, adicionar fotos e vídeos, procurar e selecionar amigos, visualizar perfis de outros usuários, enviar recados, dentre outras opções. As comunidades têm a finalidade de discutir sobre determinados temas afins, podendo ser abertas ao público ou acessadas apenas aos participantes. Nelas são encontradas informações gerais sobre a comunidade, como apresentação, data de criação, quantidade de membros, além de possuir fóruns de discussões.
} 
por determinado período, mesmo que esta não estivesse mais presente, além das visitas constantes dos familiares e amigos. A partir do século XIX, modificam-se essas formas de praticar o luto. Os enlutados passam a demonstrar o sofrimento espontaneamente ou de modo histérico para os psicólogos de hoje: chora-se, desmaia-se, desfalece-se e jejua-se, como ressalta Philippe Ariès (2003, p. 72).

Já a partir do século XX, em muitos países ocidentais, e principalmente nas zonas urbanas, nota-se geralmente o luto isolado, individual, silenciado e sem o negro na vestimenta, presente desde a Idade Moderna, no século XVI. Chorar na presença de familiares, amigos e vizinhos pode parecer vergonhoso e deprimente para muitos. E a sociedade, que nos séculos passados, se fazia presente após a morte, visitando e apoiando o enlutado, agora está em muitos casos distante, talvez pelo medo de não saber expressar as condolências adequadas ou vergonha de mostrar a dor e as lágrimas. Chora-se comumente em casa, porém não junto dos demais, e sim em um cômodo escondido, longe do círculo familiar. Essa individualização da dor da perda acaba fazendo com que a morte diga respeito apenas ao enlutado, que a vivencia desamparado.

No século $\mathrm{XX}$, além das transformações post-mortem, como observado nas práticas do luto, outros rituais funerários também sofreram alterações. A morte no século passado acabou sendo "reprimida", e a sociedade (como amigos e vizinhos) que anteriormente estava ao lado da família do morto, se faz ausente em quase todas as práticas. Alguns poucos rituais ainda persistiram em cidades do interior, como o toque dos sinos de morte e as práticas de encomendação ou missa de corpo presente, porém a variedade antes existente, como realizar um cortejo fúnebre, foi na expressão de José Rodrigues (2006, p. 163) negligenciada, transformando-se a morte e seus rituais em verdadeiros tabus.

Novos ritos fúnebres foram introduzidos nas grandes cidades ocidentais, a partir do século XX. O morto é a partir de então, em muitos casos, maquiado, negligenciando seu aspecto e aparência mórbida, através da toalete fúnebre, e o seu corpo, não mais velado na casa da família durante 24 horas, pode agora ser exposto por algum tempo na funeral home, uma espécie de hotelaria especializada em receber mortos (ARIÈS, 2003, p. 268). O mesmo ocorreu na arquitetura dos cemitérios, como nos cemitérios jardins, 
também conhecidos como cemitérios parques, que contiveram os traços mórbidos, dando a impressão ao visitante de estar em um jardim, sem a presença das ornamentações como as esculturas, tão comuns nos cemitérios secularizados.

Quanto ao luto, durante a primeira metade do século XX, em algumas cidades brasileiras, sobretudo do interior, este ainda era representado pela vestimenta preta ${ }^{2}$, pelas visitas e mensagens de condolências de parentes e amigos e pelas intervenções na vida social (resguardo dentro de casa, não podendo o enlutado, por exemplo, participar de festas), como observado na cidade de Urussanga (SC) (TOMASI, 2010). Mas, em grande parte das cidades brasileiras, o luto vai sofrendo transformações no decorrer do século passado. Entre as décadas de 1960 e 1970, o luto gradualmente vai deixando de lado seu caráter público e interativo, sendo que a vestimenta, "como sinônimo de dor cai em desuso" como enfatiza a socióloga Marisete Horochovski (2009, p. 12). E no século XXI, a individualização da dor da perda pela morte faz parte da vivência de muitas pessoas e o luto tornou-se, em muitos casos, um problema, quando não uma doença.

Contudo, contemporaneamente, uma nova forma de lidar com a perda se faz presente no mundo virtual. As práticas do luto na internet, como deixar mensagens de pêsames ou páginas on-line recordando o ente falecido, são encontradas em sites de cemitérios on-line, desde a metade da década de 1990. O MyCemetery.com ${ }^{3}$, criado no ano de 1994, nos Estados Unidos, é um exemplo desses sites, composto por páginas com memoriais de pessoas mortas. Cada falecido possui um espaço com informações gerais, como idade, biografia, nome completo, localidade que morava, motivo da morte e datas de nascimento e falecimento. Os visitantes podem incluir uma fotografia do morto, além de deixar mensagens, quase sempre demonstrando dor e saudade do falecido, como, por exemplo, "Sentimos sua falta" e "Senhor, perdoa as nossas lágrimas, e me ajuda a entender". Outros cemitérios virtuais, como o Campa Virtual ${ }^{4}$, de Portugal e o Le Cimetière Virtuel ${ }^{5}$, da França, possuem diversificadas práticas de luto. Os visitantes podem

\footnotetext{
${ }^{2}$ Às vezes a cor preta não estava em toda a vestimenta, mas ao menos em alguma peça ou fita preta presa na roupa ou no chapéu.

${ }^{3}$ Portal My Cemetery: <http://www.mycemetery.com/my/index.html>. Acesso em: 10 maio. 2013.

${ }^{4}$ Portal Campa Virtual: <http://www.campavirtual.com/>. Acesso em: 10 maio. 2013.

${ }^{5}$ Portal Le Cimetière Virtuel: <http://www.lecimetiere.net/index.php>. Acesso em: 10 maio. 2013.
} 
depositar flores e velas virtuais ${ }^{6}$ nos espaços/memoriais de cada falecido, além das mensagens de saudade, bastante frequentes nesses cemitérios on-line.

Já as práticas do luto nas redes de sociabilidade7, especificamente no Orkut, site aqui analisado, tiveram início no Brasil após sua criação, no ano de 2004. Tais redes de relacionamento virtual surgiram no século XXI, com as transformações presentes nas sociedades modernas, que tornaram acessíveis conhecer grande número de pessoas, com interesses particulares, sem sair do espaço doméstico ou do trabalho (CORRÊA, 2004, p. 4).

\section{As diversificadas experiências vivenciadas na rede de sociabilidade do Orkut}

No Brasil, o acesso dos usuários à rede social do Orkut foi intenso nos últimos anos. Uma pesquisa realizada no ano de 2009, sobre o uso das tecnologias da informação e da comunicação no território nacional, assinalou que o país liderava o número de internautas utilizando sites de relacionamento no mundo, sendo o Orkut, o mais utilizado (BARBOSA, 2009a, p. 249). A pesquisa, que teve como base 9.747 entrevistados brasileiros que utilizaram a Internet em três meses do ano de 2009, apontou que a maior porcentagem dos usuários desses sites encontrava-se na área rural, na região nordeste do Brasil e possuía nível fundamental de instrução. Quanto ao sexo e a faixa etária, os dados informaram que as mulheres eram as que mais utilizavam os sites de relacionamento, sendo as idades de 16 aos 24 anos as mais encontradas.

Percebe-se por meio dos dados, que a internet, na figura da rede social, faz parte do cotidiano de muitos brasileiros, possibilitando novas relações sociais e assumindo “papéis diversificados, conforme o contexto de seus usuários" (PERUZZO ET AL, 2007, p. 456). Essas comunidades virtuais, segundo o filósofo Pierre Lévy, são construídas a partir de uma infinidade de interesses e conhecimentos, através de projetos mútuos, em um processo de troca ou cooperação e acima de tudo, independente da proximidade

\footnotetext{
${ }^{6}$ Para depositar as flores e velas virtuais, os visitantes necessitam adquiri-las nos sites, variando o valor dos produtos, conforme o cemitério. As velas costumam "apagar" e as flores "murchar" virtualmente depois de sete dias on-line.

${ }^{7}$ Além da rede social do Orkut estão, por exemplo, a Facebook, criada no ano de 2004 e Twitter e MySpace, ambas criadas no ano de 2006.
} 
geográfica e das filiações institucionais. A comunicação por meio das comunidades virtuais não substitui "pura e simplesmente os encontros físicos: na maior parte do tempo, é um complemento ou um adicional” (LÉVY, 1999, p. 127-128).

Já o sociólogo Manuel Castells, ao abordar o surgimento das novas formas de sociabilidade virtual, ressalta algumas questões. Entre elas podem-se destacar os perigos da comunicação em rede, o isolamento social do indivíduo, a ruptura da comunicação social e da vida familiar e o desempenho de fantasias on-line. Muitas vezes, os indivíduos vivem realidades virtuais, fugindo do mundo real, sendo "difícil chegar a uma conclusão definitiva sobre os efeitos que a rede pode ter sobre o grau de sociabilidade" (CASTELLS, 2004, p. 154).

Na rede social do Orkut são vivenciadas variadas experiências, como reencontros com amigos e parentes distantes há anos, namoros virtuais ${ }^{8}$ ou novas amizades. Além da vida, a morte também está presente no Orkut: perfis pessoais de falecidos que permanecem on-line na rede ou comunidades criadas para homenagear um morto, são experiências encontradas.

\title{
“Descanse em paz, meu anjo": o luto nos perfis pessoais de falecidos
}

\begin{abstract}
"Palavras nesse momento, seriam pequenas demais para aliviar a nossa dor, pela perda dos nossos filhos, [...]. Só Deus pode aliviar esse sentimento, essa dor, que não existem palavras para descrever.

Nossos filhos fizeram e continuarão fazendo parte da vida de todos. Sempre serão lembrados com carinho, saudade e amor. Sabemos que onde eles estão, nesse momento, serão luz eterna, a iluminar os caminhos de todos aqueles que partiram de suas pequenas jornadas aqui na terra.

Pois a existência de vocês não foi em vão, [...] nesses 12 anos de existência representou simpatia, contentamento e esperança, agora vai distribuir seus sorrisos nas alturas. [...] nos seus 8 anos de vida exalou alegrias e agora vai colorir as estrelas.

[...] A dor dessa ausência será preenchida com muito amor e luz interior.

A família enlutada, muito sensibilizada, vem aqui manifestar a sua eterna gratidão, ao apoio da família, amigos, a comunidade, a todos indistintamente, pelos gestos e atitudes de ajuda prestados à família [...] nesse momento de dor infinita.

Que nossos filhos [...] descansem em PAZ!!!
\end{abstract}

\footnotetext{
${ }^{8}$ Para saber mais sobre os namoros virtuais ver (Silva; Takeuti, 2010).
} 
Um abraço a todos...Agradece a família enlutada." ${ }^{9}$ (ORKUT, 2010).

Enlutados compartilhando mensagens comoventes e emocionadas, conforme o relato acima transcrito, tornaram-se experiências bastante encontradas na rede social do Orkut entre os anos de 2004 e 2011. Nas páginas de perfis pessoais de mortos, são mães, pais, esposas, filhos e amigos enlutados, além de visitantes curiosos, que publicizam através dos variados meios, como mensagens escritas e fotografias, suas angústias, sentimentos de pesar, além da saudade do ente morto.

Na mensagem acima referida, extraída de uma atualização de um perfil pessoal de uma menina falecida, os pais descrevem a comoção e as dificuldades vivenciadas após a morte de seus dois filhos, uma menina de 12 anos e um menino de 8 anos. Além de descreverem a constante dor da perda, os pais agradecem o apoio e as centenas de mensagens de pêsames deixadas por parentes e amigos logo depois da morte, nas páginas de recados da rede social do Orkut.

Após a morte da pessoa, como já mencionado no início do trabalho, muitos familiares e amigos do falecido decidem excluir seu perfil pessoal do Orkut, sendo deletados todos os registros do perfil. No entanto, para que isso ocorra, o Orkut exige “[...] o envio de um formulário online, disponível na página do Orkut, no qual conste o verdadeiro nome do falecido, o link do perfil e o atestado de óbito digitalizado. Após três dias úteis a empresa entra em contato", conforme descrito em uma matéria do jornal Diário Catarinense (LUTO, 2010, p. 10).

Porém, outros perfis pessoais de falecidos permanecem ativos na rede. Nesses espaços, são compartilhados atualizações de perfis, recados, depoimentos e fotografias deixadas pelos visitantes da página, sobretudo pelos parentes e amigos enlutados que mantêm atualizadas e "vivas" as páginas do ente falecido.

Algumas pesquisas no Orkut são suficientes para encontrar uma grande quantidade de perfis de pessoas mortas, de modo que usuários falecidos continuam “vivos" em seus perfis pessoais e são bastante numerosos, somando, por exemplo, no

\footnotetext{
${ }^{9}$ Mensagem de atualização de um perfil pessoal de falecido. Disponível em: <http://www.orkut.com.br/Main\#Profile?uid=4856316073369943664>. Acesso em: 10 jun. 2012.
} 
ano de 2008, perto de um milhão de perfis de falecidos ${ }^{10}$, como contabiliza Talita Sales (2008).

Nessas páginas do perfil pessoal, os enlutados costumam expressar o seu pesar, seja através da atualização do perfil, informando que a pessoa faleceu, ou de uma mensagem direcionada ao morto, desejando que este tenha um descanso eterno, além de muitos descreverem o sofrimento causado pela perda. Assim, os perfis pessoais dos mortos que permanecem on-line na rede tornam-se verdadeiros lugares de memória para os que ficaram, em que o enlutado pode chorar virtualmente, conversar com o morto ou compartilhar imagens do tempo em que este vivia.

Entre os meios utilizados pelas pessoas para expressar o luto através dos perfis pessoais dos mortos, estão as mensagens de atualização, exemplificadas pelo relato exposto no início deste artigo, remetido pelos pais da menina falecida. Portanto, após a morte, muitos indivíduos, em especial os parentes e amigos, atualizam o perfil do morto ${ }^{11}$ com informações sobre o seu falecimento, como a data e motivo da morte, ou com relatos de saudade, conforme as mensagens de atualização apresentadas a seguir:

Nascido em 03/10/1964. Falecido em 10/08/2007.

(Da forma mais bela de Deus levar, Ele se foi dormindo, dormindo os sono do justo, era um servo de Deus, pois dias antes do acontecido ele aceitou Jesus Cristo como seu salvador!!). Eternamente off-line ${ }^{12}$ (grifo meu)

Pra quem conhece o nosso amigo [...] Infelizmente faleceu no dia 24/03/2008 pela tarde, num acidente de carro em Aldeia! ${ }^{13}$

\footnotetext{
${ }^{10}$ Em agosto do mesmo ano, os usuários do Orkut no Brasil chegavam a 40 milhões.

${ }^{11}$ Importante salientar, nesse sentido, que, para atualizar o perfil da rede social do Orkut, é necessário acessar através da senha e do login do usuário. Isso justifica o porquê de grande parte dos perfis pessoais dos falecidos não ter a atualização após a ocorrência da morte. No entanto, algumas pessoas conseguem a senha posteriormente, como amigos ou conhecidos do morto, conforme o relato apresentado a seguir: "Consegui a senha depois de uns dias para comunicar o falecimento de [...], esse cara divertido, amigo, leal, encantador com as mulheres, espelho para homens que não conseguiam ser como ele, muito gente fina esse cara!!! Acho que bom até demais, que Deus até o quiz bem cedo perto dele. Estou acompanhando a família dele agora, rapaz nascido na Vila da Penha, mudou se para Zona Sul, mas nunca deixou esquecida suas raizes, voltou a morar com os pais para estar por perto e cuidar deles, meio deslocado em seu retorno, tentou fazer amizades pelo orkut, mas não teve muito sucesso, pra quem o aceitou: Sinto dar essa notícia, mas ele não está mais entre nós. Forte abraço do amigo de [...]." Disponível em: <http://www.orkut.com.br/Main\#FullProfile?rl=pcb\&uid=1751195659122087989>. Acesso em: 12 jun. 2012.

12 Parte do título da dissertação provém dessa atualização do perfil pessoal de falecido. Disponível em <http://www.orkut.com.br/Main\#Profile?uid=16364096603236294228 >. Acesso em: 21 jun. 2012.

13 Atualização de um perfil pessoal de falecido. Disponível em: <http://www.orkut.com.br/Main\#Profile?uid=15673929973932757939>. Acesso em: 10 jun. 2012.
} 
Nascido em 19/09/1990 Falecido em 15/01/2009 as 8:55 am [Acidente de moto na rod. D. Pedro I - Campinas ${ }^{14}$

Percebe-se, através dessas mensagens, que muitos amigos e parentes do morto utilizam a página de abertura do perfil pessoal do falecido para comunicar e compartilhar o ocorrido e as circunstâncias do falecimento, como se fosse um obituário on-line. Deste modo, as páginas do Orkut tornaram-se um espaço de sociabilidade que comunica a morte de muitos usuários, tendo em vista que as mensagens acabam informando as pessoas sobre o falecimento, de modo que algumas, inclusive, mencionam que não sabiam sobre o ocorrido, como constatado na imagem a seguir, extraída da página de recados de um perfil pessoal de falecido:

Imagem 1 - Página de recado de um perfil pessoal de falecido

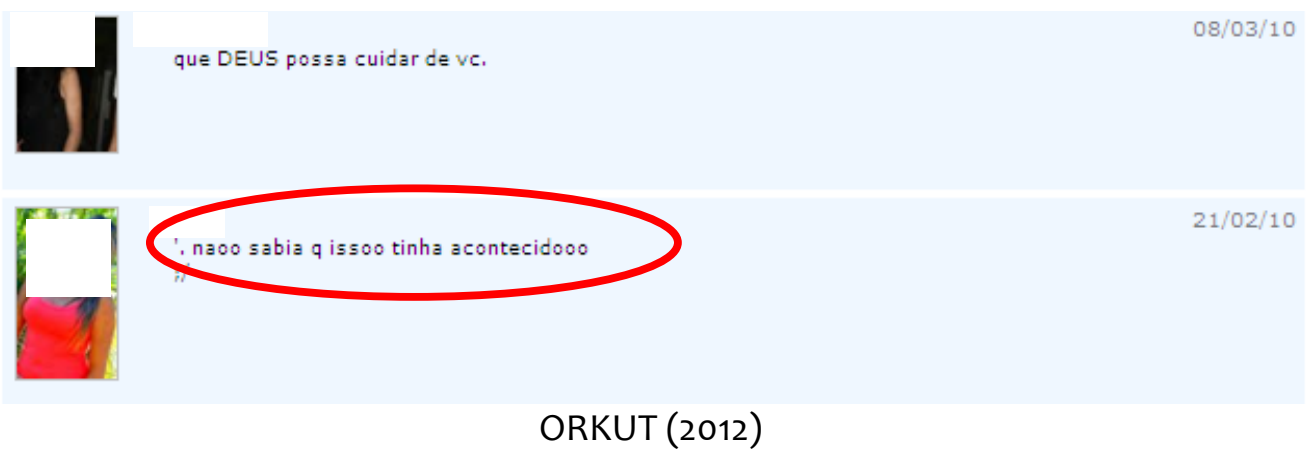

Em algumas atualizações de perfis pessoais de falecidos, a data e o horário do sepultamento também são comunicados aos visitantes, para que estes possam comparecer, como apresentado na imagem 2, retirada do perfil pessoal de uma falecida ${ }^{15}$ :

\footnotetext{
14 Atualização de um perfil pessoal de falecido. Disponível em: <http://www.orkut.com.br/Main\#Profile?uid=11065327512588306709>. Acesso em: 11 jun. 2012.

${ }^{15}$ Perfil pessoal de falecida em: <http://www.orkut.com.br/Main\#FullProfile?rl=pcb\&uid=5818123586053091167>. Acesso em: 22 jun. 2012.
} 
Imagem 2 - Atualização de um perfil pessoal de uma falecida

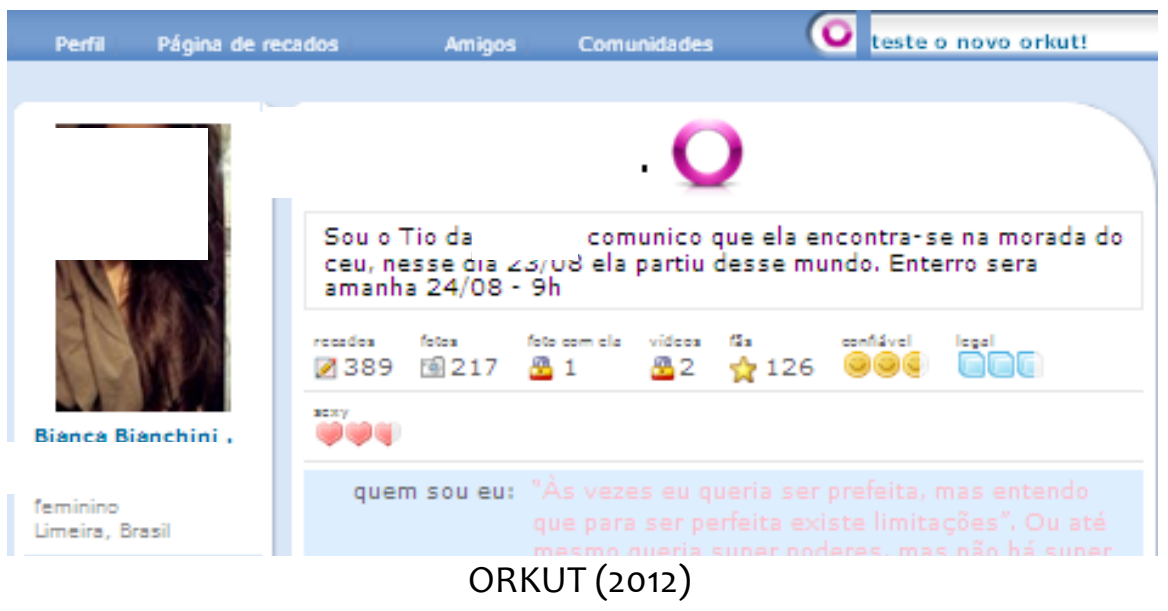

Além disso, algumas atualizações de perfis de mortos também narram a história de vida da pessoa, descrevendo desde o seu nascimento, até a sua morte, como a mensagem apresentada a seguir, compartilhada provavelmente por um amigo do falecido, que o chama carinhosamente de irmão:

[...] nascido dia 06/10/1986 nascido em Niteroi e criado em Jardim Catarina Sao Gonçalo. Aos 13 anos foi morar no Centro de Niteroi, com sua mãe [...], seu irmão mais velho [...] e sua irmã mais nova [...]. Daí começou uma nova história de sua vida. Com casa nova, lugar novo, pessoas novas, separação de seus pais, colegio novo, enfim tudo novo na sua vida. ...Em 27de Fevereiro de 2005, aos 18 anos perdeu seu irmão [...], q tinha 23 anos, em um assalto indo para o hospital ver seu filho q estava internado com meningite.

Aos 20 anos sua mãe teve um A.V.C.. E ele foi um filhão passando mais de 72 horas no hospital com ela, sem tomar banho, dormindo algumas horas da madrugada e só comendo lanchinhos.

Ele foi sim um filho, irmão muito complicado, mas também era muito carinhoso.

E em 29 de Janeiro de 2010 [...], aos 23 anos, veio sofrer um acidente de moto onde veio falecer no ato da queda, onde teve tramautismo craniano e lesões por todo o corpo e foi enterrado dia 31/01/2010.

...Saudades eternas de ti meu irmão... Foi visitar nosso saudoso [...] q nos faz tanta falta... e agora você...Você sempre estará em nossos coraçoes... ${ }^{16}$

\footnotetext{
${ }^{16}$ Atualização de um perfil pessoal de falecido. Disponível em: <http://www.orkut.com.br/Main\#Profile?uid=7199079370191975099>. Acesso em: 21 jun. 2012.
} 
O indivíduo, ao escrever a mensagem na página de entrada do perfil pessoal do morto, vai relatando o transcorrer da vida da pessoa, destacando as dificuldades, como a morte de seu irmão e a doença de sua mãe, para então chegar a sua morte, ocorrida no dia 29 de janeiro de 2010. Quem escreve a mensagem se preocupa em relatar detalhadamente as causas da morte, salientando que foi ocasionada por um traumatismo craniano, devido a um acidente de moto. Além disso, lembra do enterro, que aconteceu dois dias depois da morte, e finaliza o relato descrevendo em algumas palavras a saudade que sente do falecido e que este permanecerá no seu coração.

Além dessas atualizações dos perfis dos falecidos, as mensagens deixadas pelas pessoas nas páginas de recados são outros meios bastante utilizados para compartilhar os sentimentos de perda dos enlutados. Muitas vezes, passados dias, meses e anos da morte, as páginas de recados dos falecidos continuam alimentadas com mensagens, em especial remetidas pelos parentes e amigos do ente falecido ${ }^{17}$. Entre os recados mais encontrados, podem-se destacar os de dor, de protestos contra a morte, em especial as ocorridas tragicamente, de pêsames aos familiares enlutados, ou mensagens de condolências "direcionadas ao próprio falecido, como votos de uma boa morte: 'descanse em paz', 'descansa nos braços do Senhor', 'que Deus o tenha', 'adeus', 'saudades eternas"', como mencionam Wildoberto Gurgel, Elba Mochel e Áurea Farias (2009, p. 2).

Tais mensagens direcionadas aos mortos são frequentes, especialmente as enviadas pelos familiares dos falecidos, como esposas, pais e filhos, que utilizam as páginas de recados dos perfis pessoais dos mortos para "conversar” com o ente falecido, de modo que relatam desde experiências vivenciadas por eles após a morte, além de enfatizarem intensamente a dor causada pela perda, como exemplificado nas mensagens a seguir:

\footnotetext{
${ }^{17}$ Nesse sentido, é importante ressaltar que muitos falecidos ainda continuam recebendo mensagens de propagandas e anúncios, que são enviadas para qualquer pessoa, esteja ela viva ou morta, visto que os envios são automáticos para as listas de contatos dos anunciantes. Assim, são anúncios de viagens, vendas de produtos ou de ingressos de shows e teatros, entre outras publicidades, que acabam, muitas vezes enchendo as caixas de recados dos falecidos, como se estes ainda estivessem vivos e pudessem comparecer a tais eventos, ou comprar os produtos anunciados.
} 
Bom, hoje eu, a [...] e o [...] fomos no seu apartamento para guardar suas roupas, sabe, apesar da tristeza, da saudades... senti uma grande e verdadeira paz ao entrar ali, senti muito a sua presença, porque aquele ap tem a sua cara, o eu suor, a sua chatisse e a sua mania de um bom virginiano bitolado.... bom, so passei aqui para te dizer que as saudades ja esta pegando.... mas so o fato de saber aonde vc esta, da uma alegria... vc nada mais, nada menos esta com o todo poderoso... entao interceda por nos!!!! te amo... demais... ate um dia.. beijo (17 de novembro de $2005)^{18}$

oi meu amor...hj falei com o [...]..e falamos sobre vc!! é muito bom falar de vc sabe..eu amo falar de vc, lembrar de vc, de suas palhaçadas, de suas falas, do seu jeito..não tenho problema nenhum a esse respeito, hj tb estava arumando um album de fotos e achei o album do aniver do [...] de 1 ano.. caramba que saudades que deu.... achei uma foto de vc e do [...] juntos..que foto linda..ei, dá prá mandar uma aí de vcs juntos??? hahahahahah imagino só o que vcs dois devem estar aprontando por aí... as anjas devem estar loucas hahahahaha que maravilha saber que vcs estão bem... o FODA é as saudades isso que mata, isso que dói... mas logo logo vamos nos encontrar..essa é minha certeza.. Querido...meu querido..vele por nós, eu e seu irmão estamos passando por muitas dificuldades...um beijo no seu coração!!! (10/07/2006) $)^{19}$

oiiiiiiii. vim te dar um 'oizinho' e dizer que tamu sentindo mto a sua falta! Tem um estagiário que começou a trabalhar comigo que é mto parecido com vc [...] sinta-se abraço, meu querido!!! Beijos (13 de setembro de $2007)^{20}$ (grifo meu)

à cada dia q passa nossa filha está parecendo mais e mais com vc saudades!!!!!!!!!! se pudesse gostaria muito de voltar ao tempo... (10 de maio de 2010 $)^{21}$

Descanse em paz primo, meu principe, meu tudoooo ja esta fazendo falta te amoooooooooooo (21 de agosto de 2010) ${ }^{22}$.

Pode-se observar que tais recados, deixados para variados mortos e por diversas pessoas, como familiares e amigos do falecido, são comoventes, em especial o primeiro relato, de novembro de 2005, remetido por alguém bastante próximo ao morto. Em algumas frases, a pessoa demonstra a dor intensa causada pela morte, que ocorreu há

\footnotetext{
18 Mensagens presentes em um perfil pessoal de falecido. Disponível em: <http://www.orkut.com.br/Main\#Profile?uid=1658905819520114036>. Acesso em: 08 jun. 2012.

19 Mensagens presentes em um perfil pessoal de falecido. Disponível em: <http://www.orkut.com.br/Main\#Profile?uid=1658905819520114036>. Acesso em: 08 jun. 2012.

20 Mensagens presentes em um perfil pessoal de falecido. Disponível em: <http://www.orkut.com.br/Main\#Profile?uid=16918921015705981879>. Acesso em: 08 jun. 2012.

${ }_{21}$ Mensagem presente em um perfil pessoal de falecido. Disponível em: <http://www.orkut.com.br/Main\#Profile?uid=15673929973932757939>. Acesso em: 10 jun. 2012.

${ }_{22}$ Mensagem presente em um perfil pessoal de falecido. Disponível em: <http://www.orkut.com.br/Main\#Profile?uid=5029304766017412199>. Acesso em: 22 jun. 2012.
} 
poucos dias, além de utilizar palavras de conforto ao enfatizar que o falecido está "com o todo poderoso" e pedir que ele interceda pelos que ficaram.

Já no segundo recado, deixado por um familiar do falecido no ano de 2006, percebe-se que mesmo passados alguns meses após a morte, que ocorreu em novembro de 2005, segundo consta em outras mensagens do mesmo perfil, a pessoa descreve a sua saudade como sendo bastante dolorosa e que "mata". Salienta que após ver algumas fotos do tempo em que o ente falecido ainda vivia, a saudade ficou mais intensa, além de empregar em seu relato palavras de conforto, alegria e brincadeiras com o falecido, conforme também constatado no depoimento supracitado.

Quanto ao terceiro relato, do ano de 2007, a pessoa escreve como se estivesse conversando com o morto, saudando-o com um oi e despedindo-se com um beijo, além de destacar que sente muita falta do falecido. As outras duas mensagens, mais concisas, porém, não menos comoventes, demonstram a saudade e a dor da perda, além das conversas com o falecido, como no quarto relato, da provável companheira do morto, que diz que a sua filha está se parecendo bastante com ele, além de mencionar que desejaria muito regressar ao passado.

Outra característica presente em variados perfis pessoais de falecidos é que muitas das páginas de recados já são bastante acessadas no próprio dia da morte da pessoa, sendo que os usuários do Orkut já as utilizam para destacar seu sofrimento e tristeza, além de muitos demonstrarem não acreditar que a pessoa tenha realmente morrido:

Nesta madrugada meu irmão foi para junto de Nosso Senhor. Descanse em PAZ MEU IRMÃO! (15/11/05) $)^{23}$

SIM AMIGOS NOSSO [...] FALECEU NESTA MADRUGADA, SEU CORPO SERÁ VELADO, NO CEMITÉRIO 'JARDIM DA PAZ' AQUI EM SÃO JOSÉ DO RIO PRETO. Orem por ele, e pela família enlutada. [...] DEUS te Abençoe e te llumine!!! Fique na LUZ de DEUS, junto a Jesus. (29 de agosto de 2010) Desde ontem de manha estou chorando sem parar, não sei oq esta acontecendo, só sei que esta doendo! doi muito, dooi de saber que voce esta indo embora! ontem, eu te chamei, mas voce não acordou, voce não me respondia [...], porque? eu preciso de voce aqui poxa! TE AMO DE MAIS MEU AMOR. (30 de agosto de 2010)

\footnotetext{
23 Mensagens presentes em um perfil pessoal de falecido. Disponível em: <http://www.orkut.com.br/Main\#Profile?uid=1658905819520114036>. Acesso em: 08 jun. 2012.
} 
Sera que voce entende que eu preciso de voce aqui pra poder viver? voce se foi, tão rapido, levou todo o meu amor, todo o meu ar, toda minha luz.. hoje eu te liguei pra voce ir na sorveteria comigo comprar doce como agente sempre fazia, mais voce não me atendeu :( voce não me responde mais amor ;/ vooolta, eu não quero viver sem voce. EU TE $\mathrm{AMO}^{24}$ (30 de agosto de 2010)

As mensagens enviadas pelos enlutados, minutos ou horas após a morte, são certamente as mais comoventes, transtornadas e desesperadas. Os últimos dois depoimentos, enviados pela mesma pessoa, no dia 30 de agosto de 2010, demonstram que ela não quer acreditar que a morte realmente tenha ocorrido. Relata não entender porque a pessoa morreu, porque não responde mais seus chamados, além de pedir desesperadamente para que o ente morto retorne. Quanto ao segundo recado sobredito, também encontrado no mesmo perfil que as duas mensagens posteriores, o depoente descreve o local que será realizado o velório, além de pedir orações pelo morto e pela família enlutada, algo bastante comum entre os visitantes das páginas.

Passados alguns dias da morte, muitos dos perfis pessoais têm seu número de mensagens ampliado, de forma que algumas se distinguem pela estreita relação com os rituais de morte, como os variados comunicados sobre as missas realizadas em intenção ao morto, como as missas de sétimo dia, um mês e um ano após a morte. Em um único perfil pessoal, de um homem que faleceu no dia 15 de novembro de 2005, com apenas 31 anos, são encontrados nas mensagens três comunicados referentes às missas encomendadas para a alma do falecido, como se pode constatar a seguir:

\author{
“MISSA DE $7^{\circ}$ DIA \\ $2^{\mathrm{a}}$ FEIRA \\ $21 / 11 / 05$ \\ 20:00 Horas \\ Igreja: NOSSA SENHORA DA SAÚDE \\ Metrô Santa Cruz \\ Contamos com a sua presença. \\ Obrigado. [...] (18 de novembro de 2005) \\ Missa de 01 mês de Falecimento. \\ 5a. Feira - $15 / 12$ - 19 horas \\ Igreja da Cidade Dutra. (14 de dezembro de 2005)
}

\footnotetext{
${ }^{24}$ As últimas três mensagens estão presentes em um mesmo perfil pessoal de falecido. Disponível em: <http://www.orkut.com.br/Main\#Profile?uid=702073039917348276>. Acesso em: 15 jun. 2012.
} 


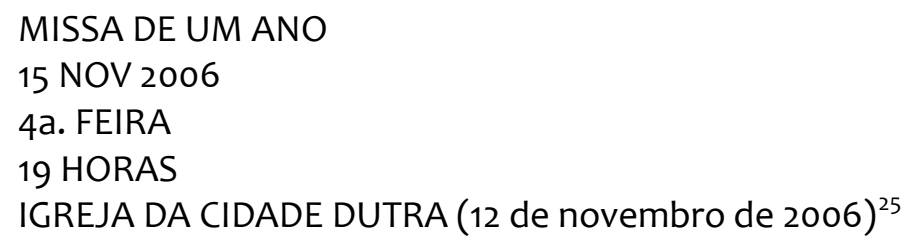

Tais missas, sobretudo as de sétimo dia, um mês e um ano de morte, segundo Marisete Hoffmann Horochovski (2009), possuem significados especiais e são fundamentais para os familiares e amigos católicos do falecido, em especial para aqueles que estão passando por momentos bastante dolorosos e sofridos, comum à grande maioria dos enlutados. Para a mesma pesquisadora, a missa de sétimo dia é um grande evento de orações para os falecidos e um meio de confortar os vivos, sendo que dela "participam os parentes, os amigos, os conhecidos que participaram, ou não, dos ritos de separação. É praticamente obrigatória e o número de participantes, assim como nas outras práticas, varia de acordo com a admiração por aquele que partiu e com os laços da comunidade" (HOROCHOVSKI, 2009, p. 11).

Já a missa de um mês de falecimento, é para Marisete Horochovski (2009, p. 11), "restrita ao círculo de intimidade e atualmente feita apenas por católicos praticantes", enquanto que a missa de um ano de falecimento caracteriza-se, para o catolicismo, como um verdadeiro "fechamento de um ciclo que coroa a integração da alma no outro mundo." (HOROCHOVSKI, 2009, p. 11).

Outra particularidade frequente nas páginas do Orkut é o ato de enviar mensagens na página de recados do perfil pessoal do falecido após meses ou mesmo anos da morte, de forma que nos aniversários de morto os recados são bastante encontrados, conforme constatado em alguns dos relatos a seguir:

Nossa! Hoje faz um ano que estamos sem você... sabe, neste mesmo dia no ano passado, estávamos todos destruídos por dentro, querendo entender o que se passou com você... O tempo passou, 1 ano, o nosso dia-a-dia fez com que a dor passasse e foi mais difícil pra uns, menos pra outros... mas eu conheço 2 pessoas que ainda estão sofrendo muito com sua perda, pessoas que precisam encontrar serenidade, uma delas é sua mãe, a outra é sua namorada, tente interceder por elas daí, de onde você

\footnotetext{
25 Mensagens presentes em um perfil pessoal de falecido. Disponível em: <http://www.orkut.com.br/Main\#Profile?uid=1658905819520114036>. Acesso em: 08 jun. 2012.
} 
está... sei que está ao lado de nosso amado Jesus, e conheço (bem de perto) a misericórdia dele... por favor ajude-as... Sábado estivemos no aniversário da sua afilhada [...], revi toda a sua família, matei as saudades da sua mãe, dos seus irmãos, tias, primos... estavam todos lá... e sei que você também não faltou... você também estava lá... Estamos com saudades... sempre estaremos... sempre lembro das coisas engraçadas que você dizia, pra lembrar de você com alegria... Relaxa amigo! Todos nós vamos ficar bem... Um beijo. (15 de novembro de 2006) ${ }^{26}$

Hoje está fazendo 4 meses sem você minha lindinha... mas NÃO tenho esquecido de você! Que Deus te guie por toda a eternidade. Fique na Santa Paz... AMÉM...(07 de fevereiro de 2008 )

Hoje faz 1 ano de muitas saudades. Amo você [...]. Fique com Deus! (07 de outubro de 2008) ${ }^{27}$

Irmão, não escrevi antes não sei bem o porque, mas hoje, bateu um vontade sei la

algumas coisas mudaram, algumas para melhor outras nem tanto,

a vida continua corrida, com alguns problemas e alguns desafios, e tambem tem coisas boas acontecendo, sua afilhada esta crescendo, esta muito esperta e muita bela tambem, esse dias ela perguntou por você, sabe ela te chama de padrinho do ceu, e me perguntou sobre você, foi muito bonito ver a emoção dela com apenas 3 anos de idade, ao ouvir falar de você.

O [...] tambem esta crescido e bem sapeca, ta um verdadeiro muleque, bom o quanto você faz falta não presciso escrever e o quanto os nosso papos na padaria me faz sentir saudades tua é uma coisa gigantesca que o tempo não cura, mas a saudade me [f]az lembras dos momentos bacanas que passamos juntos.

sei que você fez sua parte e muito bem. mas sinto muitas saudades.

Irmão, cumpadre, amigo abraço. (14/01/2009) $)^{28}$

Venho aqui matar a saudade e... Tem hs que não acredito! ${ }^{29}$ (9 de maio de 2010) (grifo meu)

Nota-se que no primeiro depoimento, enviado por uma amiga do falecido, exatamente um ano após a morte, a preocupação com alguns enlutados é evidente, mencionando que a mãe e namorada do falecido ainda sofrem profundamente com a morte. Também fala sobre a saudade que sente, além de mencionar que a dor da sua perda pode ser sentida de variadas formas, uns sentindo mais pesar do que outros. E tal

\footnotetext{
26 Mensagens presentes em um perfil pessoal de falecido. Disponível em: <http://www.orkut.com.br/Main\#Scrapbook?uid=1658905819520114036>. Acesso em: 08 jun. 2012.

${ }^{27}$ As duas últimas mensagens estão presentes em um mesmo perfil pessoal de falecido. Disponível em: <http://www.orkut.com.br/Main\#Profile?uid=13626803598938524930 >. Acesso em: 10 jun. 2012.

${ }_{28}$ Mensagens presentes em um perfil pessoal de falecido. Disponível em: <http://www.orkut.com.br/Main\#Scrapbook?uid=1658905819520114036>. Acesso em: 08 jun. 2012.

${ }_{29}$ Mensagem presente em um perfil pessoal de falecido. Disponível em: <http://www.orkut.com.br/Main\#Profile?uid=2524713658354376086>. Acesso em: 08 jun. 2012.
} 
fato pode ser realmente observado entre muitas famílias enlutadas, tendo em vista que dependendo do grau de parentesco ou mesmo da ligação afetiva que a pessoa tinha com o morto, a duração do luto pode variar, já que alguns enlutados podem demonstrar seu pesar por mais tempo, enquanto outros podem expressar mais brevemente, como algumas semanas ou meses.

Do mesmo modo, as outras duas mensagens subsequentes, extraídas de um mesmo perfil pessoal, também foram remetidas nos aniversários de morte, do quarto mês e um ano de falecimento, de modo que a pessoa destaca a saudade, o não esquecimento e o amor pelo seu ente falecido. Quanto aos outros relatos, o quarto inicia explicando o motivo de não ter escrito a mensagem ao morto anteriormente, enfatizando, no entanto, que hoje sentiu uma grande vontade de Ihe escrever. Menciona, entre as diversas coisas, que a sua vida está bastante agitada, além de contar ao morto como sua afilhada, de três anos de idade, se emociona ao ouvir falar do padrinho, e por fim, fala da saudade que sente do amigo morto, como dos momentos bons que eles viveram juntos.

Já a última mensagem, apesar de bastante sucinta, enfatiza uma questão central para esta pesquisa. A pessoa deixa registrado que acessa a página do perfil pessoal do morto para poder matar a sua saudade, ou seja, este é seguramente um lugar de memória para a pessoa que escreve, tendo em vista que os lugares de memória são caracterizados por Pierre Nora como sendo híbridos, mistos, enlaçados de vida e morte, marcos de outra era, restos, e antes de tudo locais não de história, mas de memória (NORA, 1993, p. 12-13). Como bem resume Ulpiano Bezerra de Meneses (2009, p. 450), um lugar de memória vai desde um objeto material e concreto, como um artefato ou uma paisagem, até um objeto abstrato, podendo então uma página da internet ser caracterizada como um lugar de memória.

Além das mensagens lembrando os aniversários de morte e as missas em intenção ao falecido, o aniversário de nascimento também é uma data especialmente recordada, sobretudo entre os enlutados, que deixam registrados nos recados as lembranças daquela data, ainda tão importante para os que ficaram. Tais mensagens enviadas pelos amigos e familiares do morto no dia de aniversário de nascimento são, sem dúvida, as 
mais encontradas nas páginas de recados dos perfis pessoais dos mortos ${ }^{30}$, conforme as expostas a seguir:

aeee. ahh kra acredito que em algum lugar vc ta vendo a mensagem kra... tenho que te dizer que tu faz falta pros amigos..e acredito que vc esta ai no céu festejando o teu aniversario Parabensss [...] abraço (10 de maio de 2007) ${ }^{31}$ (grifo meu)

Msm vc tando la em cimaa te desejo os Parabenss!!que vc fiquei em paz... $(03 / 10 / 08)^{32}$

Hoje seria comemorado mais um aniversário seu aqui no plano material... mas sei que os anjos estão ao teu lado no plano espiritual te cobrindo de bênçãos e te iluminando... Fique na presença de Deus...Te amo de montão...Saudades... (30 jul de 2010) ${ }^{33}$

eeu to com muita saudadeee, logo hooje que agente ja tinha combinado de iir pra THE , fazeer festa :/ mais Deus sabe de tudo, e o céeu deve ta fazendo festa aai :( SAUDADEEES DEMAIS, NAUM SEI COMO TO AGUENTANDO ... aah, hoje noooós suas amigas rezamos um paai nossso e cantamos tua musica favoritaa ..meu ajinho da guarda :/ (17 de agosto de 2010) $)^{34}$

Estas mensagens, enviadas nos dias de aniversário de nascimento dos falecidos, possuem a mesma finalidade, que é a de parabenizar a pessoa, apesar desta já ter falecido, de modo que alguns reforçam inclusive que o morto vai vê-la de algum lugar, como se constata no primeiro relato. A grande maioria dessas mensagens remetidas no dia do aniversário do morto possui um aspecto bastante melancólico, visto que esta data é para muitos enlutados um dia de profunda tristeza, como notado no último depoimento, enviado por uma amiga de uma menina que morreu com 12 anos. Em algumas frases, a menina se mostra bastante inconsolada com a morte da amiga, que aconteceu repentinamente, segundo examinado em outras mensagens presentes no perfil. Esta ressalta os planos que havia feito antes da morte da amiga, como o de festejar

\footnotetext{
${ }^{30}$ Tal fato pode ser explicado devido à mensagem automática que a rede social do Orkut envia a lista de contatos, lembrando o aniversário da pessoa. Assim, mesmo depois da morte, mensagens continuam sendo remetidas aos amigos do falecido, recordando a data de seu aniversário de nascimento.

31 Mensagens presentes em um perfil pessoal de falecido. Disponível em: <http://www.orkut.com.br/Main\#Profile?uid=16918921015705981879>. Acesso em: 08 jun. 2012.

32 Mensagem presente em um perfil pessoal de falecido. Disponível em: <http://www.orkut.com.br/Main\#Profile?uid=16364096603236294228>. Acesso em: 22 jun. 2012.

33 Mensagem presente em um perfil pessoal de falecido. Disponível em: <http://www.orkut.com.br/Main\#Profile?uid=13626803598938524930 >. Acesso em: 10 jun. 2012.

34 Mensagem presente em um perfil pessoal de falecido. Disponível em: <http://www.orkut.com.br/Main\#Profile?uid=4856316073369943664>. Acesso em: 10 jun. 2012.
} 
o seu aniversário, além de destacar que naquele dia, ela e outras amigas rezaram e cantaram para a menina falecida, finalizando o relato com a mensagem "meu anjinho da guarda", uma forma muito carinhosa de se referir à falecida, e também um meio de confortar sua dor.

Além do aniversário de nascimento, outras datas comemorativas são notadamente lembradas pelos familiares e amigos do morto, como o dia de Natal, de finados, dos pais, das mães e das crianças, conforme as mensagens expostas a seguir, que foram enviadas próximo ao dia de Natal. Nelas, pode-se perceber a tristeza que este dia passou a representar para os que escrevem, devido à ausência dos entes que morreram:

Querido.... hoje tive um lindo sonho com vc, pareceu real... acordei ate feliz... matei um pouquinho as saudades que sao muitas....pensei muito em vc no natal, ate escorreram algumas lagrimas, mas nao falei pra ninguem pra nao gerar mais tristezas... como vc sempre sera especial em nossas vidas... que falta... que buraco [...] beijo no coraçao (27 de dezembro de 2005$)^{35}$

Infelizmente mais um natal sem você, mas o que me conforta é saber que estais ao lado de Deus e que estais bem. S A U D A D E S... (23 de dezembro de 2008) $)^{36}$

Em suma, nota-se que as mensagens textuais presentes nas páginas de recados dos perfis pessoais dos falecidos são dos mais variados fins, sendo elas enviadas por diversas pessoas, como amigos, familiares ou conhecidos do morto, possuindo todas elas, no entanto, uma intenção bastante evidente - a de mostrar a tristeza e o pesar que os acompanha diariamente após a morte dos entes falecidos.

Outro meio utilizado pelos enlutados para expressar sua dor, são as mensagens deixadas no campo “depoimentos”, do perfil pessoal do falecido. Menos encontradas do que as mensagens enviadas nas páginas de recados e nas atualizações de perfis, os depoimentos deixados para os mortos são bastante interessantes, como se pode ver na imagem 3, com dois depoimentos enviados ao morto.

\footnotetext{
35 Mensagens presentes em um perfil pessoal de falecido. Disponível em: <http://www.orkut.com.br/Main\#Profile?uid=1658905819520114036>. Acesso em: 08 jun. 2012.

36 Mensagem presente em um perfil pessoal de falecido. Disponível em: <http://www.orkut.com.br/Main\#Profile?uid=13626803598938524930>. Acesso em: 10 jun. 2012.
} 


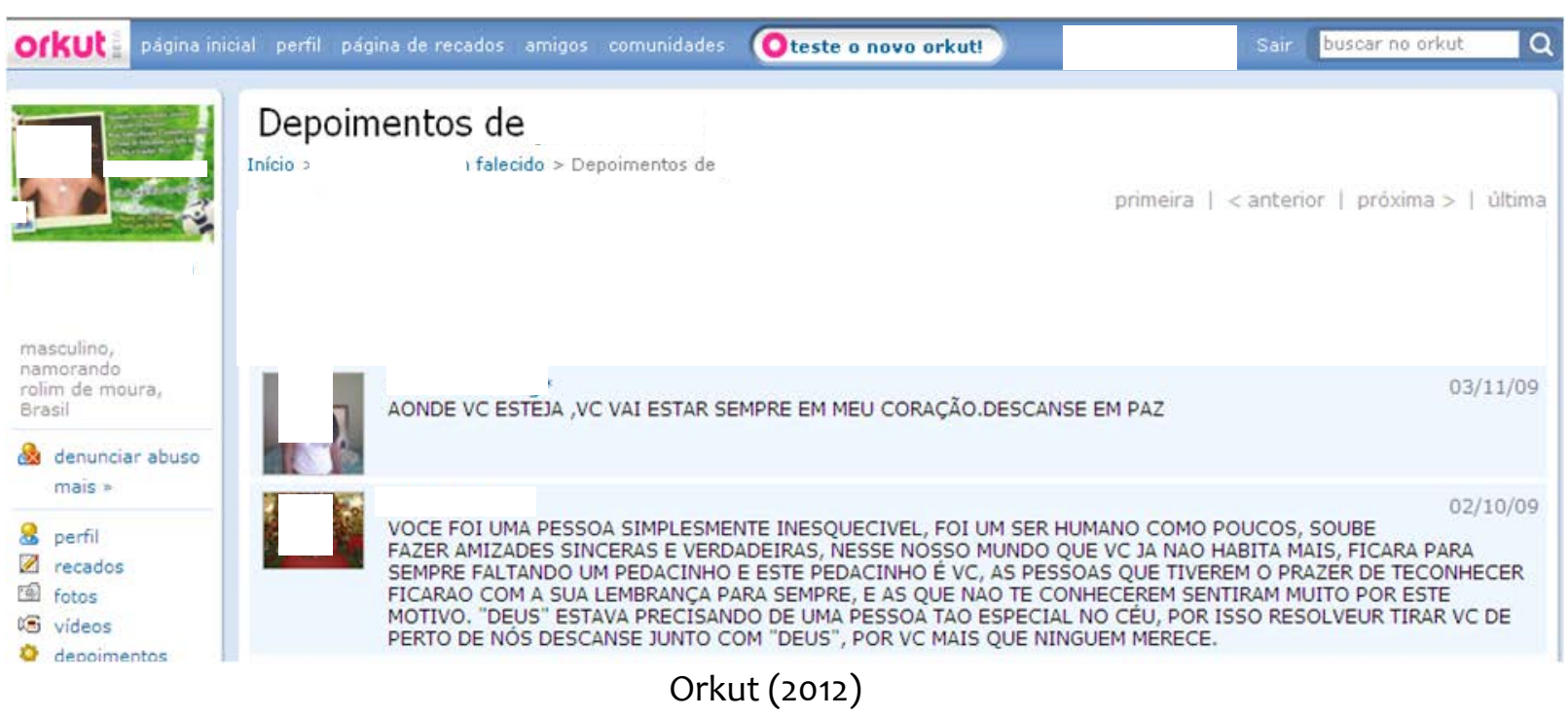

Todavia, além das mensagens textuais presentes nas páginas de recados, nos depoimentos e nas atualizações de perfis de falecidos, as imagens também se tornaram uma forma dos enlutados expressarem e compartilharem sua dor, como se constata nos álbuns de fotos, que são espaços nos perfis pessoais que permitem a inserção de fotografias e imagens através de álbuns.

Após a morte, muitos familiares e amigos passam a utilizar os álbuns de fotos do perfil pessoal do falecido para inserir e compartilhar fotografias e imagem relacionadas aos entes, sendo que algumas imagens são bastante peculiares, como fotografias da sepultura do morto (Imagem 4 e Imagem $5^{37}$ ) e as lembrancinhas de missa de sétimo $\mathrm{dia}^{38}$ (Imagem 6 ${ }^{39}$ ), conforme já destacado no início deste trabalho.

\footnotetext{
$37 \quad$ Fotografias

disponíveis em: <http://www.orkut.com.br/Main\#FullProfile?rl=pcb\&uid=322601191288429913>. Acesso em: 20 abr. 2011. ${ }^{38}$ Segundo Julia Massucheti Tomasi (2010, p. 90), as lembrancinhas de missa de sétimo dia, lembrancinhas de morte ou cartão de recordação, eram, até o final do século XX, quase sempre entregues nas missas de sétimo dia, conforme constatado na cidade de Urussanga (SC). Nesse "cartão, o conteúdo é bastante diversificado, possuindo informações, como por exemplo, nome completo do ente, data de nascimento e morte, foto do falecido, frases que 'sintetizem' o que o morto foi em vida, poesias, fragmentos bíblicos, orações ou imagens sacras (como de cristo e santos)."

39 Fotografia disponível em: <http://www.orkut.com.br/Main\#Profile?uid=8150338412269499492>. Acesso em: 22 abr. 2011.
} 
Imagem 4 - Fotografia da sepultura do falecido, no dia de finados, no álbum de fotos do seu perfil pessoal do Orkut

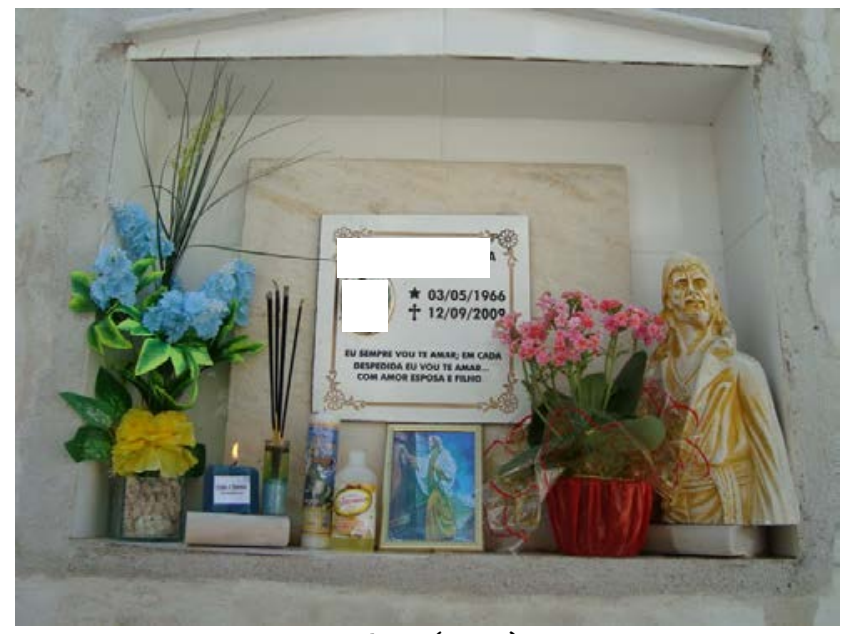

Orkut (2011)
Imagem 5- Fotografia da sepultura do falecido, no álbum de fotos do seu perfil pessoal do Orkut

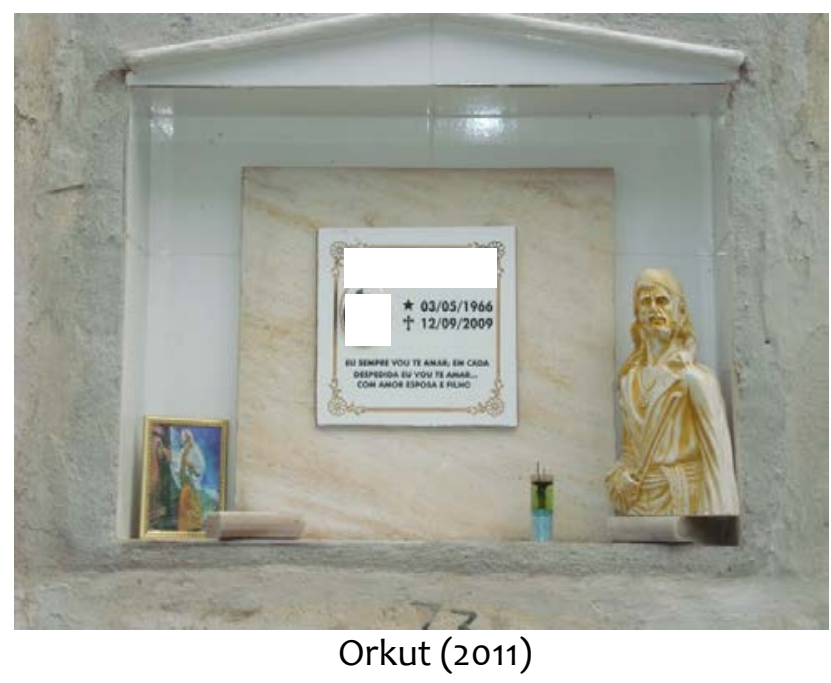

Imagem 6 - Lembrancinha de morte em um perfil pessoal de falecido

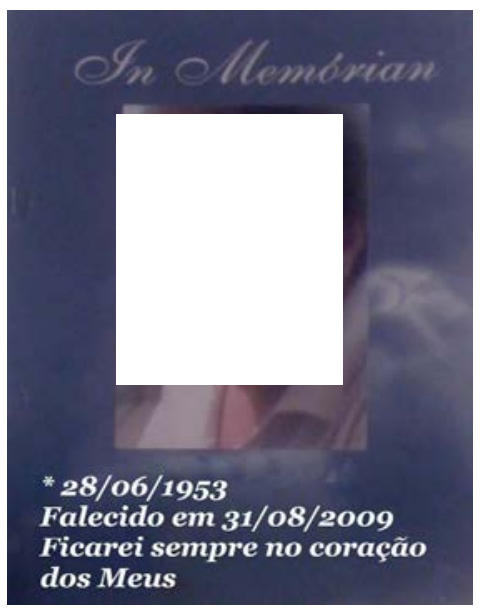

Orkut (2011)

As fotografias da sepultura do falecido, acima apresentadas, que se caracterizam por ser bastante incomuns nos perfis pessoais de falecidos, foram publicadas pela esposa do morto, sendo que a primeira tem como legenda "minha ultima Homenagem pra vc meu amorrr...", e a segunda: “te amo pra sempre!!! fique com DEUS ..."40. Percebe-se então, que a companheira do falecido postou as fotos como uma forma de manifestar a

\footnotetext{
${ }^{40}$ Legendas disponíveis em:

<http://www.orkut.com.br/Main\#AlbumZoom?gwt=1\&uid=10388098161897746857\&aid=1257220460\&pid=12 57246122119>. Acesso em: 20 abr. 2011.
} 
sua última homenagem feita ao ente, mostrando a sua sepultura em formato de lóculo, com uma lápide contendo os dados do ente e um epitáfio que diz "Eu sempre vou te amar; Em cada despedida eu vou te amar... Com amor esposa e filho." Uma das fotografias, tirada no dia de finados, como destaca a enlutada em uma das mensagens deixadas no álbum de fotos, mostra que juntamente da sepultura estão dois arranjos de flores e velas, que provavelmente foram levados ao cemitério pela companheira do falecido no dia dos mortos.

Quanto às lembrancinhas de morte, elas são encontradas em diversos perfis pessoais de falecidos, sendo utilizadas por muitos enlutados como uma forma de homenagear o ente morto, de modo que grande parte delas é postada logo após a morte, gerando a partir de então comentários bastante comoventes, tanto de familiares como de amigos e conhecidos do falecido, conforme imagem e comentários expostos a seguir:

Imagem 7 - Lembrancinha de morte e seus comentários post-mortem em um perfil pessoal de falecido

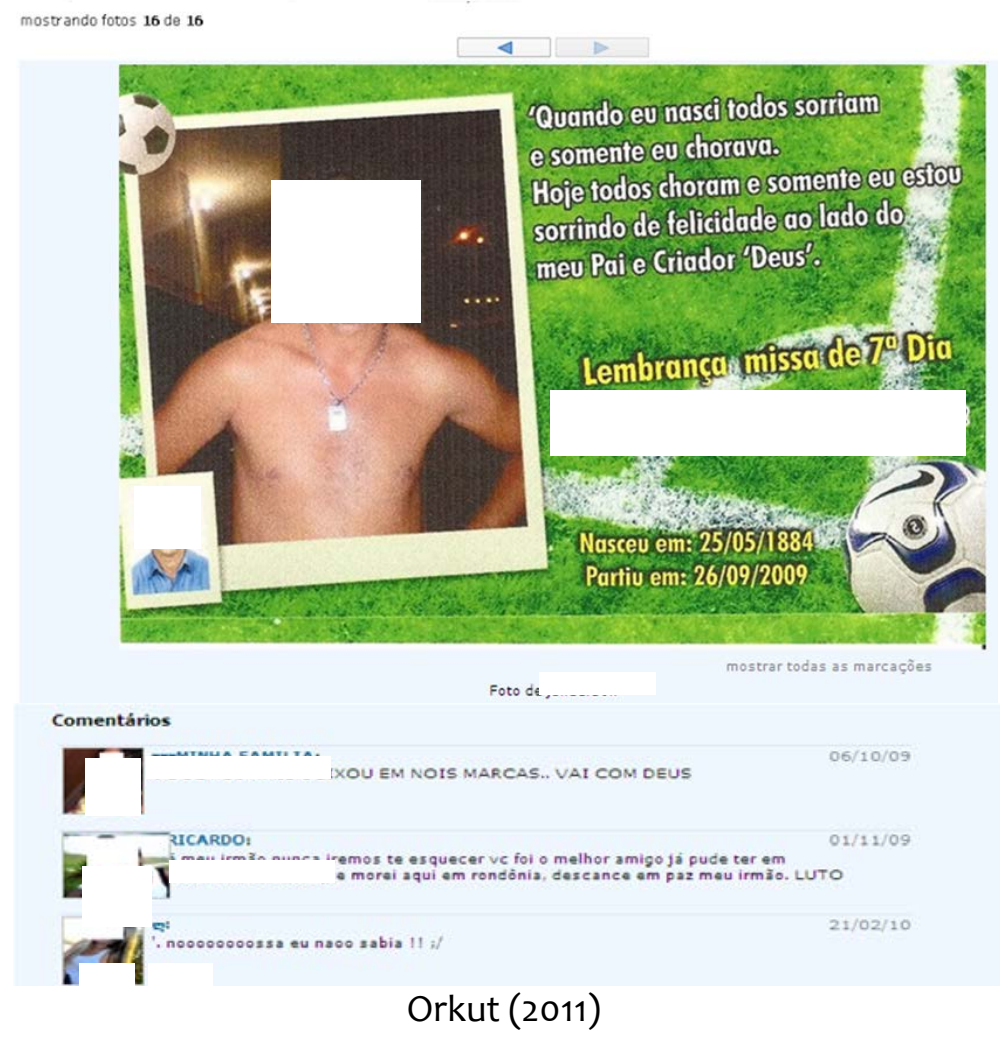


Outros tipos de imagens também são compartilhados pelos enlutados, como os exemplos a seguir, presentes em um perfil pessoal de uma mãe enlutada ${ }^{41}$, que postou diversas fotografias editadas de seu filho falecido, com mensagens e poesias que remetem a saudade e ao amor eterno:

Imagem 8 - Fotografia de um ente falecido, com mensagens de saudade, em um perfil pessoal de uma mãe enlutada.

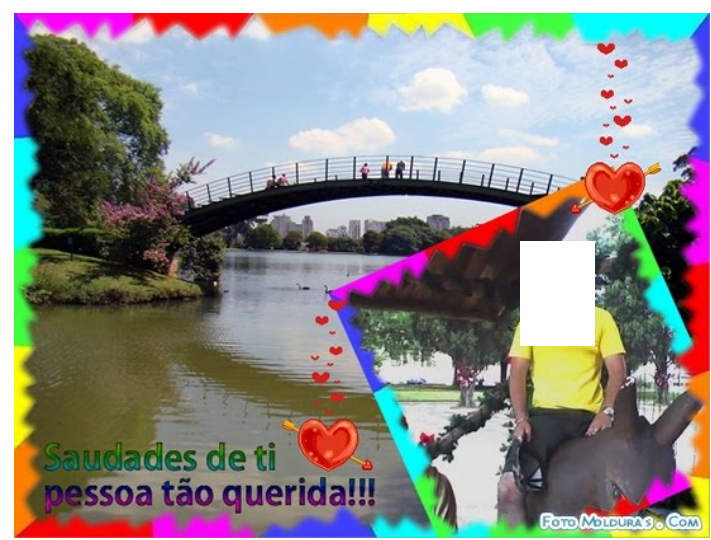

Orkut (2012)
Imagem 9 - Fotografia de um ente falecido, com mensagens de saudade, em um perfil pessoal de uma mãe enlutada.

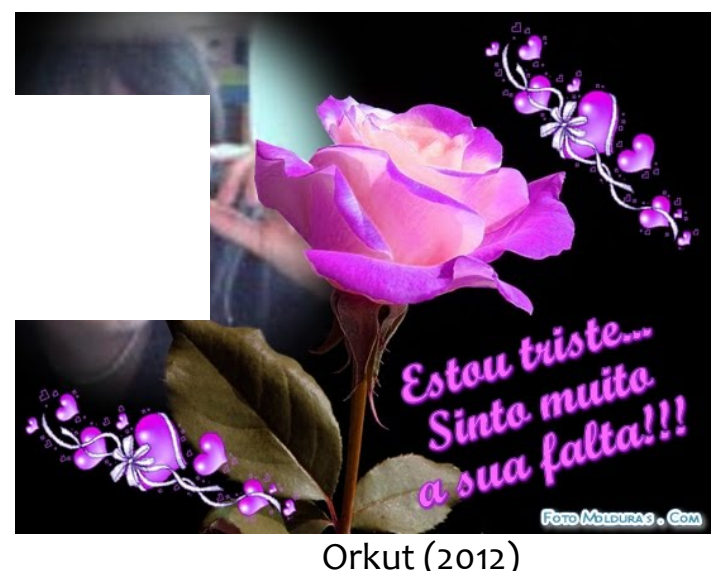

Além dessas imagens postadas após a morte do ente, fotografias anteriormente inseridas no seu perfil pessoal também acabam promovendo comentários post-mortem bastante emocionados e comoventes, conforme se examina na imagem e nos comentários expostos a seguir:

\footnotetext{
${ }^{41}$ Perfil pessoal disponível em: <http://www.orkut.com.br/Main\#Album?uid=461789539062723301\&aid=1261765393>. Acesso em: 08 jun. 2012.
} 
Imagem 10 - Fotografia e comentários post-mortem em um perfil pessoa de falecido

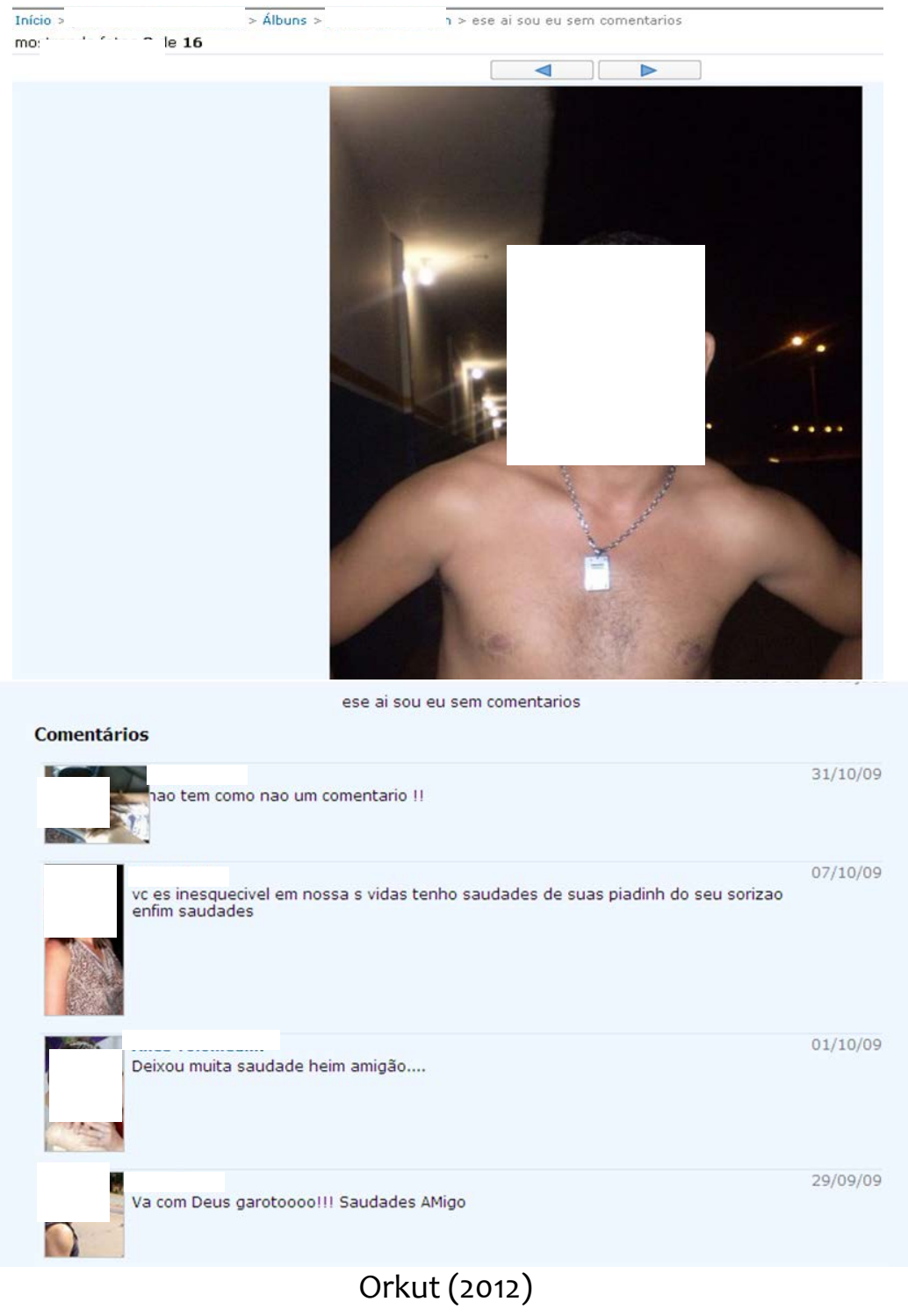

Tal fotografia inserida pela pessoa antes da sua morte, com o título "ese ai sou eu sem comentarios" [sic], gerou comentários entristecidos de amigos e familiares do falecido logo após a morte, que ocorreu no dia 26 de setembro de 2009. Estes demonstram a dor e a saudade intensa que sentem do ente. Isso é explicado, segundo o antropólogo Mauro Koury (2002), pelo fato de que a fotografia do ente morto acaba por congelar aquele momento ali exposto, remontando lembranças do tempo em que este ainda vivia, visto a imagem estar substancialmente ligada à emoção, sendo "a primeira o recipiente da segunda, confundindo-se" (KOURY, 2002). E, diversas mensagens presentes 
em perfis pessoais de falecidos comprovam tais constatações, como um relato já exposto anteriormente, de uma enlutada que recorda através de fotografias as experiências vividas ao lado do ente falecido.

Além das características dos perfis pessoais de falecidos já apresentadas no decorrer desse artigo, como as mensagens de dor nas páginas de recados, nos depoimentos, nas atualizações de perfis e nos comentários das fotografias, como também as imagens postadas e compartilhadas com os usuários da sua rede do Orkut, devem-se destacar alguns perfis que se distinguem pela peculiaridade. Um dos casos é o perfil pessoal de uma menina de 14 anos, que foi assassinada por seu ex-namorado no dia 26 de agosto de 2010, segundo notícias do Diário do Para ${ }^{42}$ (2010). No seu perfil, os relatos de dor, sofrimento e indignação pela morte brutal são os mais encontrados:

Foi muita covardia o que fizeram com vc [...].Espero que a justiça seja feita e que esse vagabundo seja capturado logo. FICO COM DEUS, VC VAI FAZER MUITA FALTA!!!! TE AMO. (28 de agosto de 2010)

Vai com Deus. Isso q fizeram com vc foi covardia. Mas eu sei q vc ta em um lugar melhor! [...]. Luto por ti $\$ (30 de agosto de 2010)

PRIMA A JUTIÇA FOI FEITA ESSE MOSTRO Ñ IA FICA SOUTO...DEUS E TÃO BOM Q ELE VEIS Q FOSSE PRESO NO DIA DO DEU ANIVERSARI.......OBRIGADO MEU DEUS...... (08 de setembro de 2010) ${ }^{43}$.

Alguns dias após a morte, que ocorreu no final do mês de agosto de 2010, o acusado de tê-la matado já havia sido preso, conforme informa uma das mensagens supracitadas que foi enviada pela prima da falecida, no dia 08 de setembro de 2010. Outra característica que se pode observar, segundo o mesmo perfil, é que muitos dos amigos e parentes da falecida incluíram juntamente com o seu nome pessoal do Orkut as palavras: “[luto], em Luto pelo meu amor!!!, amiga te amo, [luto] vai na fé”, entre outras, como uma forma de homenagear a falecida e protestar contra a morte que ocorreu tragicamente.

\footnotetext{
42 Para saber mais, ver a reportagem: "Polícia caça o acusado de matar a ex-namorada", do Diário do Pará (2010). Disponível em: <http://www.diariodopara.com.br/N-108551POLICIA+CACA+O+ACUSADO+DE+MATAR+A+EX-NAMORADA.html>. Acesso em: 22 jun. 2012.

43 Mensagens presentes em um perfil pessoal de falecido. Disponível em: <http://www.orkut.com.br/Main\#Profile?uid=1373117223082166571>. Acesso em: 08 jun. 2012.
} 
Outro perfil pessoal de falecido que merece destaque devido às especificidades encontradas é o perfil de um homem que morreu com 27 anos, no dia 14 de março de 2010. Segundo uma comunidade da rede social do Orkut ${ }^{44}$, seu corpo estava desaparecido há alguns dias, depois que o seu bote virou e caiu no rio Mogi Guaçu (SP). No seu perfil pessoal, durante as buscas pelo corpo, os familiares e amigos deixaram recados esperançosos com o reencontro, além de palavras de consolo aos demais visitantes que aguardavam ansiosamente por notícias:

Meu Anjo é assim q a gente sempre se fala sei q vc vai voltar pra mim o mais rapido possível sem vc não sou nada vc me deu td de bom nessa vida alegria e me faz a pessoa mais feliz desse mundo vamos juntos realizar todos os nossos planos vc vai ver meu anjo Deus te deu pra mim e foi um presente maravilhoso (15 de março de 2010)

Te Amooooooooodooooooooooo e eu [...] vc sabe Deus não vai nos separar pq ele nos uniu de uma forma tão maravilhosa q não [é] possivel separar anjooooooo00000000 estou te esperando Amooooooooooooooo vooooooceeeeeeeeeeee (15 de março de 2010) amigo a [...] ta aqui esperando vc pra coloca-la em cima do seu carro e começar a seção fotos rsrsrsrsr a Esperança é a ultima que morre, e eu tenho muita em vc....vai dar tudo certo amigão.... força e volta logo e não deixa a gente mais triste em... (15 de março de 2010)

amigo onde vc estiver volte logo estamos esperando valeu abraço. (15 de março de 2010)

Oi anjo estou esperando vc me acordar como sempre

cade o meu bom dia coração eu sei q vc vai volta

Deus não vai permitir q vc va embora assim Te Amo.

eu confio e acredito em Deus..... (16 de março de 2010) ${ }^{45}$

Após a notícia da morte, confirmada no dia 16 de março de 2010, foi intensa a quantidade de mensagens de dor e pêsames nas páginas de recados do falecido, além de uma mensagem com o local e o horário da missa de sétimo dia, e dos vários recados enviados depois de meses e anos da morte:

Oi amigo,e agora,abri os meus recados do orkut e cadê o seu recado pra mim me desejando parabéns???

o que vai ser da gente???

\footnotetext{
44 Comunidade PGM, da rede social do Orkut. Para saber mais, ver: <http://www.orkut.com.br/Main\#CommMsgs?cmm=993780\&tid=5510141328512218361>.

$45 \quad$ Mensagens presentes em um perfil pessoal de falecido. Disponível em: <http://www.orkut.com.br/Main\#Scrapbook?uid=6282299063552209094>. Acesso em: 08 jun. 2012.
} 
nos dê força ai de cima,pois não está fácil não.

descance em paz,

vc sempre estará em nossos corações.amamos vc. (16 de março de 2010)

Meus sentimentos a familia.

E a vc, dencanse em paz ! (17 de março de 2010)

DIA 20/03 MISSA DE $7^{\circ}$ DIA DO [...]

ÁS 19:30 NA PAROQUIA NOSSA SR. APARECIDA.

ESTÃO TDS CONVIDADOS! (19 de março de 2011)

Meu Anjo.......dois meses sem te ver sem te ouvir sem essa sua alegria como vc faz falta aki q saudade de vc.......... (14 de maio de 2010)

3 meses sem vc! q falta me faz (14 de junho de 2010)

Oiiii meu Anjo........pode passar dias ......mesês.......e anos.......

mas nada vai conseguir apagar o que vivemos

nunca vou deixar de TE Amar a saudade machuca

mas os lindos momentos q passamos juntos ficou

as lindas lembraças ......... SAudade.............(04 de outubro de 2010)

mano qui sdds du c brow

1 ano hj eim i num da pa acredita ainda.

cara vc sempre sera lembrado na memoria i no coraçao di todos

[...] sdds eternas (14 de março de 2011) ${ }^{46}$

Percebe-se que mesmo após a confirmação da morte, muitos dos visitantes da página não conseguiam acreditar no que realmente havia acontecido. E igualmente a diversos outros perfis pessoais de falecidos, as mensagens continuaram sendo remetidas ao morto, mesmo depois de meses e anos da morte, sendo que elas passam a sintetizar, para muitos enlutados, a constante dor da perda.

Enfim, o perfil pessoal do falecido tornou-se para muitos enlutados um lugar de memória, em que se pode chorar e conversar virtualmente com o ente morto através das mensagens. Certamente, para muitos enlutados, visitar o perfil pessoal do falecido é um meio de estar mais próximo do ente, seja ele filho, mãe ou amigo, considerando que o Orkut podia ser um local em que a pessoa vivia constantemente novas experiências, se divertindo, conhecendo novos sujeitos ou revendo amigos distantes. Portanto, como bem sintetiza um dos relatos retirados de um perfil pessoal de falecido, já exposto anteriormente "Venho aqui [no perfil pessoal do morto] matar a saudade e... Tem hs que não acredito!" 47 . Com efeito, o Orkut é para muitos enlutados um lugar que se vai matar a

\footnotetext{
46 Mensagens presentes em um perfil pessoal de falecido. Disponível em: <http://www.orkut.com.br/Main\#Scrapbook?uid=6282299063552209094>. Acesso em: 08 jun. 2012.

47 Mensagem deixada no dia 9 de maio de 2010, em um perfil pessoal de um falecido. Disponível em: <http://www.orkut.com.br/Main\#Profile?uid=2524713658354376086>. Acesso em: 08 jun. 2012.
} 
saudade do ente, como é o cemitério e a sepultura do falecido para muitos indivíduos que perdem alguém próximo.

\section{Considerações finais}

Enfim, são então experiências de vida e também de morte, que tornaram a rede social do Orkut um universo gigantesco, atualmente pouco acessado, quando não totalmente esquecido pelos seus antigos usuários. Como bem lembra um internauta, o Orkut "é o melhor site que existe... dá até pra acessar do outro mundo.. aff (16 de julho de 2005)", o que significa dizer, do mundo da morte, ou como denominam outros internautas, do mundo off-line. Além de possibilitar que o internauta conheça novas pessoas, converse com o namorado e bata papo com um desconhecido, o Orkut, conforme descrito no decorrer deste artigo, se tornou um espaço para vivenciar e expressar o luto de muitos indivíduos, em especial dos familiares e amigos do morto, como ressaltado nas mensagens apresentadas a seguir, deixadas pela irmã de uma falecida:

e já fazem 3 anos, e você está fazendo 17. talvez esse recado seja inútil , mas pelo menos é uma forma de eu conseguir me expressar, não sei, me sentindo melhor, um dia isso vai acabar, eu sei que vai.

Eu te amo muuito, 17 anos, é impossivel não ficar triste ou qualquer coisa, e o nosso amor está acima tudo, minha irmã (07 de novembro de 2008) Lembro de um bilhete que você me deixou falando do seu sonho de que ainda iriamos viajar juntas pelos States... Eu realizei ele por você, por mim e por nós :')

Me sinto bem escrevendo aqui, já que não tenho como lhe dizer, é como se você o estivesse lendo, miss u like i never want to (24 de agosto de $2010)^{48}$

Assim, através do levantamento realizado nas páginas da internet, percebeu-se que muitos enlutados mantiveram on-line e atualizadas as páginas dos perfis pessoais dos entes falecidos, mesmo passados anos da sua morte. Seja porque o ente morto gostava do Orkut, ou porque ali que passava a maior parte do seu tempo, o Orkut se tornou, sem

\footnotetext{
48 Mensagens presentes em um perfil pessoal de falecido. Disponível em: <http://www.orkut.com.br/Main\#Scrapbook?uid=15726428565501399551>Acesso em: 22 set. 2012.
} 
dúvida, um espaço para lembrar e recordar as experiências vivenciadas com o falecido, como descrito na mensagem supracitada. A enlutada expõe que deixar um recado no perfil pessoal da sua irmã falecida é uma forma de conseguir se expressar, de se sentir melhor, ou seja, de vivenciar melhor o seu luto.

Esta irmã da falecida é um exemplo dos muitos enlutados encontrados que deixaram registradas dezenas de mensagens no perfil do ente, mesmo depois de anos da morte, tendo em vista que a sua irmã faleceu no início do mês de julho de 2005, e ainda no ano de 2011, seus recados são postados nas páginas da falecida como: "tem tanta coisa acontecendo, eu queria tanto que voce tivesse aqui pra eu te contar tudo pra voce me ajudar, porra, 6 anos.. te amo." ${ }^{49}$ (05 de julho de 2011).

Com efeito, percebe-se que muitos enlutados veem o Orkut como um espaço para compartilhar e publicizar o sofrimento e o pesar pela morte do ente, seja através dos seus próprios perfis pessoais, dos perfis dos entes mortos ou das comunidades da rede. Mas, neste contexto, como explicar tais práticas em tempos de morte silenciada e interdita, onde o trabalho do luto se distingue, sobretudo, pela solidão, introspecção e individualismo? Seria uma nova forma de os enlutados trabalharem a sua perda?

Sem dúvida, o Orkut se transformou em um novo espaço virtual utilizado pelos enlutados para compartilharem sua dor diária, conforme constatado no decorrer deste trabalho. A vergonha para demonstrar o sofrimento e a aflição interna, tão comum entre os enlutados da contemporaneidade, se faz quase que ausência na maioria dos relatos escritos deixados nas páginas, como nota-se na mensagem comovente exposta a seguir, escrita por uma mãe enlutada: "Filha, eu amo você! coração da mamãe esta apertadinho de tanta saudades, sinto falta do teu sorriso, da cara safada nas brincadeiras, sinto falta ate do seu cheiro, mamita [...] te ama muito!" 50 .

Alguns enlutados inclusive se desculpam e pedem perdão ao morto, por não terem sido o que esperavam ser, durante o período em que o ente vivia, como exposto no exemplo a seguir: "Sei que você não vai ler...mas me sentiria mal se não mandasse, assim

\footnotetext{
49 Mensagem presente em um perfil pessoal de falecido. Disponível em: <http://www.orkut.com.br/Main\#Scrapbook?uid=15726428565501399551>Acesso em: 22 set. 2012.

50 Mensagem presente em um perfil pessoal de falecido. Disponível em: <http://www.orkut.com.br/Main\#Scrapbook?uid=15726428565501399551>Acesso em: 22 set. 2012.
} 
como me senti mal quando te perdi e percebi que não pude ser o amigo que você foi para mim..."(24 de dezembro de 2005) ${ }^{51}$.

Em suma, são os aniversários, os Natais, os dias das mães, dos pais, das crianças, e mesmo os dias de finados, datas tão marcantes para os que ficaram, que fazem os enlutados e os amigos do falecido visitarem seus perfis e comunidades do Orkut. Estas visitas virtuais são para muitos um meio de estar mais perto do ente, tendo em vista que as páginas do Orkut são espaços que possibilitam rememorar e reviver as experiências vividas com a pessoa, de modo que os enlutados costumam então ali demonstrar a saudade causada pela perda, por meio dos recados, depoimentos, fotos e mensagens.

\section{Referências Bibliográficas}

ARIÈS, Philippe. História da morte no Ocidente. Rio de Janeiro: Ediouro, 2003.

BARBOSA, Alexandre F. Pesquisa sobre o uso das tecnologias da informação e da comunicação no Brasil: TIC Domicílios e TIC Empresas 2009. São Paulo: Comitê Gestor da Internet no Brasil, 2009a. Disponível em: <http://op.ceptro.br/cgi-bin/indicadores-cgibr2009?pais=brasil\&estado=sc\&academia=academia\&age=de-16-a-24anos\&education=superior\&purpose=pesquisa-academica>. Acesso em: 29 mar. 2011.

BARBOSA, Aline da Silva Néto. Orkut: o espaço que possibilita a visibilidade e a imortalidade. In: Congresso Brasileiro de Ciências da Comunicação, 32., 2009, Curitiba Anais eletrônicos... Curitiba: 2009b. Disponível em:

<http://www.intercom.org.br/premios/2009/AlineBarbosa.pdf>. Acesso em: 17 mar. 2011.

CASTELLS, Manuel. A galáxia internet: reflexões sobre internet, negócios e sociedade. Lisboa: Fundação Calouste Gulbenkian, 2004.

CORRÊA, Cynthia Harumy Watanabe. Comunidades virtuais gerando identidades na sociedade em rede. Ciberlegenda, Rio de Janeiro, 2004. UFF. $n^{\circ} 13$. Disponível em: <http://www.portugaliza.net/numero02/comunidades_virtuais_identidades.pdf >. Acesso em: 25 mar. 2011.

GURGEL,Wildoberto Batista; MOCHEL, Elba Gomide; FARIAS, Áurea Mariana Costa. Luto eletrônico: forma contemporânea de manifestação de luto. In: Congresso Brasileiro de Enfermagem, 61, 2009. Fortaleza. Anais Eletrônicos... Fortaleza: Centro de Convenções do 51 Mensagem presente em um perfil pessoal de falecido. Disponível em:
<http://www.orkut.com.br/Main\#Scrapbook?uid=15726428565501399551>Acesso em: 22 set. 2012. 
Ceará, 2009. Disponível em:

<http://www.abeneventos.com.br/anais_61cben/files/indices.pdf>. Acesso em: 10 jun. 2012.

HOROCHOVSKI, Marisete Teresinha Hoffmann. No tempo do "guardamento": rituais de morte narrados por velhos. In: Congresso Brasileiro de Sociologia, 14, 2009. Rio de Janeiro. Anais Eletrônicos... Rio de Janeiro: UFRJ, 2009. Disponível em: <http://starline.dnsalias.com:8080/sbs/arquivos/15_6_2009_11_51_3.\%20Hoffmann\%20Hor ochovski.pdf >. Acesso em: 10 abr. 2011.

KOURY, Mauro Guilherme Pinheiro. Uma fotografia desbotada: atitudes e rituais do luto e o objeto fotográfico. João Pessoa: Manufatura/GREM, 2002.

LÉVY, Pierre. Cibercultura. São Paulo: Ed. 34, 1999.

LUTO na internet: web tornou-se ambiente para discutir a morte. Diário Catarinense, Santa Catarina, 22 ago. 2010. Consultado na Biblioteca Pública do Estado de Santa Catarina (BPESC).

MENESES, Ulpiano Toledo Bezerra de. Cultura política e lugares de memória. In: AZEVEDO, Cecília et al. (Orgs.); Cultura política, memória e historiografia. Rio de Janeiro: FGV, 2009. p. 445-463

NORA, Pierre. Entre memória e história. A problemática dos lugares. Projeto História, n. 10, p. 7-28, dez. 1993.

PERUZZO, Alice Schwanke et al. A expressão e a elaboração do luto por adolescentes e adultos jovens através da internet. Estudos e Pesquisas em Psicologia, Rio de Janeiro: UERJ, v. 7, n. 3, p. 449-461. dez. 2007. Disponível em: <www.revispsi.uerj.br/v7n3/artigos/pdf/v7n3a08.pdf>. Acesso em: 28 mar. 2011.

RODRIGUES, José Carlos. Tabu da morte. 2. ed. Rio de Janeiro: FIOCRUZ, 2006.

SALES, Talita. ORKUT: há vida após a morte. Blogspot Matina, 2008. Disponível em: <http://matinauniao.blogspot.com/2008/12/orkut-h-vida-aps-morte.html>. Acesso em: 15 ago. 2010.

SILVA, Vergas Vitória Andrade da; TAKEUTI, Norma Missae. Formas de experimentar o amor romântico num namoro virtual. RBSE - Revista Brasileira de Sociologia da Emoção, v.9, n.26, pp.398-455, João Pessoa, GREM, 2010.

TOMASI, Julia Massucheti. Eternamente Off-Line: as práticas do luto na rede social do Orkut no Brasil (2004-2011). 2013. 178 p. Dissertação (mestrado) - Universidade do Estado 
de Santa Catarina, Centro de Ciências Humanas e da Educação, Mestrado em História, Florianópolis, 2013.

TOMASI, Julia Massucheti.. Morte à italiana: os ritos funerários no município de Urussanga (SC) no decorrer do século XX. 2010.120 p. Monografia (graduação) - Universidade do Estado de Santa Catarina, Centro de Ciências Humanas e da Educação, Cruso de História, Florianópolis, 2010. 